\title{
O culto imperial e o Apocalipse de João
}

\author{
José Adriano Filho, Paulo* \\ Augusto de Souza Nogueira**
}

\section{Resumo}

O culto imperial teve um papel importante na produção do Apocalipse de João. O livro contém várias imagens extraídas do seu âmbito, mas a descrição das realidades celestiais e mobilização da igreja na terra que apresenta são transformadas por meio da construção de uma realidade contracultural. Essa contracultura assume os valores da cultura greco-romana, mas os inverte. O livro cria sua própria estrutura de referência, um tipo de imagem que espelha a cultura original, a partir da qual aquele que habita essa reconstrução da realidade social encontra o status de autoestima que a cultura de origem lhes nega. Sua crítica ao poder vigente transcende sua localização histórica particular e questiona suas pretensões de universalidade e eternidade, tornando o Apocalipse uma voz importante do cânon cristão e uma testemunha das lutas da humanidade no estabelecimento de uma comunidade justa e fraterna.

Palavras-chave: Religião e poder. Culto Imperial. Apocalipse de João.

\section{The imperial cult and John's Apocalypse Abstract}

The Imperial cult played an important role in the production of John's Apocalypse. The book contains several images taken from its realm, but its description of the' heavenly realities and mobilization of the Church on earth are transformed by the construction of an anti-cultural reality. The counter culture presented assumes the values of GrecoRoman culture, but reverses them. The book of Revelation creates his own frame of reference, a type of image that mirrors the original culture, from which he who inhabits this reconstruction of social reality has the status of self-esteem that the culture of origin denies them. The religious critique of prevailing power it presents transcends its particular historical location, and questions its claims to universality and eternity,

\footnotetext{
* Faculdade Unida de Vitória. Doutor em Ciências da Religião (Universidade Metodista de São Paulo), doutor em Teoria e História Literária (UNICAMP), professor da Faculdade Unida de Vitória. E-mail: j.adriano1@uol.com.br .

** Universidade Metodista de São Paulo. E-mail: profpaulonogueira@outlook.com.br.
} 
making Revelation an important voice of the Christian Canon and a witness of the struggles of humanity in establishing a just and fraternal community.

Keywords: Religion and Power. Imperial Cult. Revelation of John.

\section{El culto imperial y el Apocalipsis de Juan}

\section{Resumen}

El culto imperial tuvo un papel importante en la producción del Apocalipsis de Juan. El libro contiene varias imágenes extraídas de su ámbito, pero la descripción de las realidades celestiales y la movilización de la iglesia en la tierra que presenta son transformadas por medio de la construcción de una realidad contra la cultura. Esta contracultura asume los valores de la cultura grecorromana, pero los invierte. El libro crea su propia estructura de referencia, un tipo de imagen que refleja la cultura original, a partir de la cual aquel que habita esta reconstrucción de la realidad social encuentra el estatus de autoestima que la cultura de origen les niega. Su crítica al poder vigente trasciende su ubicación histórica particular y cuestiona sus pretensiones de universalidad y eternidad, haciendo del Apocalipsis una voz importante del Canon cristiano y un testigo de las luchas de la humanidad en el establecimiento de una comunidad justa y fraterna.

Palavras clave: Religion y poder. Culto imperial. Apocalipsis de Juan.

Como a humanidade a ele se dirige assim [como Sebastos], de acordo com sua estima de sua honra, reverencia-o com templos e sacrifícios em ilhas e continentes, organizados em cidades e províncias, em igual medida a grandeza de sua virtude e para compensá-lo pelos benefícios que a ela presta (NICOLAU DE DAMASCO, FGH 90 F 125).

Visto o imperador presidir, deste modo, ao Império e este estar estruturado em direção a ele (imperador) enquanto seu vértice, e dele emanar todo o poder de comando, torna-se ele a mais alta representação do Império [...] Numa situação em que o imperador ocupava posição tão saliente, dificilmente se podia evitar que a pessoa do imperador fosse sublimada, especialmente em sentido religioso e, depois, cultualmente venerada. [...] Se o imperador representa o império de tal modo que o bem comum se baseia na sua integridade, então a não-participação nos atos rituais, que devem celebrar e confirmar a incolumidade do imperador, levanta a suspeita de deslealdade política fundamental (WENGST, 1991, p. 70-75).

Na sociedade romana, Pax Deorum, Mos Maiorum e Pax Romana estavam intimamente interligados, de forma a fornecer a fundamentação da ordem social, política e religiosa (RHEE, 2005, p. 13-14; 159-160). Nesse contexto, o culto imperial, ancorado na ideologia imperial de poder, tornou-se central para a unidade da sociedade romana desde a época do governo de Augusto 
(29 a.C.-14 d.C.). ${ }^{1}$ O termo "culto imperial" é genérico, o fenômeno em si não era homogêneo, mas uma síntese carregada de tensão entre a ideologia do culto helenístico ao soberano, o qual via na pessoa do imperador a epifania de um deus, e as concepções romanas da personalidade extraordinária favorecida pelos deuses, ou seja, os romanos veneravam os poderes transcendentes que, em circunstâncias especiais, podiam manifestar-se em personalidades que se destacavam na sociedade. Nos tempos da República, já no Oriente, honras divinas foram tributadas aos generais vitoriosos (culto aos heróis), que sucediam no poder os soberanos helenistas (Pompeu), enquanto em Roma se evitava tratar os dirigentes do Estado como deuses (ACOSTA BONILLA, 2007, p. 27-28).

O culto imperial envolve também concepção e iconografia da revolução da era de Augusto, na arquitetura, religião e sociedade (ZANKER, 1988). Ele se apresenta como um fenômeno complexo e variado, com muitos fatores determinantes de sua origem. O culto ao Imperador teve um papel importante na composição do Apocalipse de João. O livro contém imagens extraídas e adaptadas do seu âmbito. Esse é o caso na descrição das realidades celestiais e a mobilização da comunidade fiel na terra que são transformadas por meio da construção de uma realidade contracultural. Essas imagens - os anciãos diante do altar do trono celestial, as vestes brancas dos mártires, a linguagem dos hinos, as orações do santuário celestial, as imagens da mãe, da criança e dos anjos, a apresentação dos monstros "do mar" e "da terra", a descrição da "prostituta" e da "Babilônia" - estão relacionadas com o culto imperial. A contracultura do Apocalipse inverte essas imagens ao assumir os seus valores, mas lhes atribui novos significados. As narrativas do livro oferecem às comunidades fiéis uma identidade a partir da periferia

Ao delimitar o que é "culto imperial" é preciso ter cuidado para não justificarmos nossos próprios conceitos sobre religião em detrimento das distinções que os antigos faziam da relação entre religião e política. A dicotomia existente entre os conceitos atuais de religião e política são construções modernas. Religio significava reverência, consciência e diligência para com os superiores, não exclusivamente os deuses: "Ser religioso não é meramente respeitar a santidade dos deuses, mas também ser respeitosos (officiosus) para com os homens". A palavra religião era também usada coletivamente como designação dos ritos e cerimônias do culto divino e de tudo que está ligado a ele (res divinae oposta a res bumanae). A religio pré-cristã não estava preocupada com virtudes pessoais e interiores, mas com comportamento e atitude exterior, ou seja, estava preocupada com a observância e não com a fé, com a ação e não com o sentimento. Isso, naturalmente, não quer dizer que tais pessoas não experimentavam emoções durante os seus cultos, mas que esse aspecto não era central ao conceito e significado de religio (GRADEL, 2002, p. 4). 
do império, sendo, talvez, a diferença mais importante entre o discurso do culto imperial e o discurso do Apocalipse a avaliação do papel da violência na História (FRIESEN, 2002, p. 3-4).

\section{1 - O culto imperial e sua difusão}

Ao chegarem à bacia oriental do Mediterrâneo (220 a.C.), os romanos entraram em contato com o culto helenístico ao soberano. Naquela ocasião, os habitantes da Grécia e da Ásia Menor atribuíram honras divinas aos generais vitoriosos que assumiram o poder no lugar dos soberanos helenistas. Eles também instituíram a veneração da deusa Roma, concebida como a personificação do poder do Estado e das virtudes do povo romano, sendo um dos testemunhos mais antigos desse fato a construção do templo em honra a Roma, em Esmirna (195 a.C.). Mais tarde, a reação do leste grego após a derrota de Antônio, de modo diferente de Roma que não precisava de novos símbolos ou imagens visuais, foi aplicar a antiga e arraigada "linguagem" do culto helenístico ao soberano ao novo monarca. O poder do novo monarca, que "trouxe a paz e restaurou a ordem, era visível em todos os lugares, sendo-lhe concedidas as honras normalmente concedidas aos deuses do Olimpo" (FÍLON, Legatio 149-51, cf. PRICE, 2004, p. 58-61). As formas exteriores do novo culto eram as mesmas que as cidades gregas utilizaram para honrar Alexandre e os reis helenísticos, Roma e os generais romanos, mas agora o culto imperial representava um novo fenômeno. Os gregos precisavam enfrentar a nova situação, que lhes exigia integrar a política e a superioridade militar romana em sua concepção de mundo e identidade. Nesse contexto, a transposição das categorias helenísticas do culto aos governantes como benfeitores e salvadores foi uma das estratégias que lhes permitiu realizar isso com êxito. No período anterior a Augusto, o culto ao governante ocorria em uma ou em outra cidade, em especial numa ocasião particular, mas a partir desse momento passou a ocorrer tanto nas cidades "livres" quanto nos centros administrativos das províncias e em lugares que não tinham status cívico (ZANKER, 1988, p. 297-298).

Em Roma, após a vitória de Otavio (Augusto) em Actium (31 a.C.), "paz e segurança" foram impostos ao Império por seu "Salvador". Essas "boas novas" se espalharam por meio do culto imperial. A partir de Augusto, portanto, o culto ao dirigente apresenta uma mudança significativa. A assembleia da Ásia decidiu, por volta de 29 a.C., oferecer uma coroa "à pessoa que concebeu as mais excelsas honras para o deus” (ou seja, Augusto). 
Quando a coroa foi finalmente entregue no ano 9 a.C., a assembleia explicou os motivos de seu desejo de honrar Augusto:

Considerando que a providência que divinamente ordenou nossas vidas criou com zelo e magnanimidade o mais perfeito deus para nossas vidas ao produzir Augusto e infundi-lo de virtude em benefício da humanidade, enviando-nos e aos que vem depois de nós um salvador que levou a guerra a termo e estabeleceu todas as coisas; considerando que Cesar (Augusto), ao aparecer, excedeu as esperanças de todos os que tinham ansiado por bons ventos, não só superando os benfeitores nascidos antes dele, como também deixando aos que vêm qualquer esperança de superá-lo; considerando que o nascimento do deus para o mundo o começo de bons ventos por meio de seu advento (PRICE, 2004, p. 58-59).

Augusto desenvolveu o reinado sacral que César já havia iniciado, mas impôs reservas para ser adorado, numa atitude que, sem dúvida, era uma mescla de discrição e urgência, ou, mais diretamente, um disfarce, que não permitissem elementos que fossem além de uma veneração formal, mas explorou ao máximo as possibilidades de uma ascensão numinosa de sua posição e terminou aceitando a sua veneração nas províncias romanas do oriente. As cidades da Ásia Menor lhe proclamavam honras como seu libertador. No ano 27 a.C., Augusto permitiu a construção de um templo em Éfeso em honra da deusa Roma e ao Divus Julius e, em Pérgamo, outro templo foi construído em sua honra e às divindades de Roma. Os habitantes de Metilene (25 a.C.) já celebravam o aniversário do imperador (KOESTER, 2005, p. 370-372). Nesse contexto, pode-se explicar por que as inscrições da Ásia Menor se dirigem a Augusto como "Divino Salvador da raça humana" e o "Autor da Paz".

Há duas inscrições que refletem o desenvolvimento do culto imperial na época de Augusto. Uma, a inscrição de Halicarnasso, impossível de datar, apresenta Augusto como o "Pai da vida", "Salvador do gênero humano"; por ele se vive em paz, por ele florescem a ordem da lei, a concórdia, a harmonia e a prosperidade abundante. Em sua honra hão de se fazer imagens, tributar cânticos, celebrar festas e sacrifícios. A outra, a inscrição de Priene (9 a.C.), que representa o decreto de introdução do calendário juliano na Ásia Menor, sublinha a coincidência dos aniversários de Augusto com o "princípio da vida e da existência", pelo que é necessário que todas as províncias deem graças por tão grandes benefícios e que celebremos o nascimento do divino César 
(PRICE, 2004, p. 58). A assembleia das cidades da Ásia aceita o imperador como salvador e a aparição de Augusto é entendida como a "boa notícia de todos", assinalando o dia do nascimento de deus e o começo das boas novas para o mundo:

(E difícil de dizer) se o nascimento do excelso César é uma questão de maior prazer ou maior benefício. Poderíamos com justiça considerá-lo equivalente ao começo de todas as coisas, e ele restaurou, ao menos ao ponto de tornar útil, se não ao estado natural, toda forma que se tornara imperfeita e caíra em infortúnio; e ele conferiu um aspecto diferente ao mundo inteiro, que teria abraçado, dada a sua fragilidade, sua própria destruição, não tivesse César nascido para o benefício comum de todos. Assim sendo, agem com acerto as pessoas que consideram ter sido isso o começo do alento da vida para elas, o ponto que estabeleceu um limite ao arrependimento por ter nascido. E como ninguém pode receber um começo mais auspicioso par ao bem comum e individual de nenhum outro dia do que esse dia que trouxe a fortuna para todos...; e como é difícil agradecer na devida medida os grandes benefícios que ele trouxe a não ser que, em todos os casos, devêssemos conceber algum novo método de compensação, cumpre que as pessoas celebrem com maior prazer seu nascimento como um dia comum a todos se algum prazer especial lhes tiver sido concedido graças ao seu governo; em consequência, pareceme próprio que o nascimento do excelso César sirva para todos os cidadãos como o próprio Dia do Ano Novo (apud PRICE, 2004, p. 59).

Esse decreto é considerado evangelia imperial ("boa nova"), cujo sujeito único é o imperador. Os decretos ("boas novas") imperiais afetavam a todos os habitantes do Império Romano. Em geral, eles anunciavam o nascimento do imperador, sua maioridade, sua ascensão ao trono, a recuperação da sua saúde e suas vitórias militares como meio para conquistar a paz.

Após a morte de Augusto, para homenagear os seus méritos, o senado romano também publicou as Res Gestae, um escrito atribuído ao próprio Augusto, que menciona suas conquistas, mas foi financiado por pessoas que buscavam sua promoção ou por autoridades locais que queriam alcançar o status de "amigo de César" ou "amigo de Roma". O texto exalta a figura de Augusto como símbolo do império e garante da paz ao ressaltar alguns sinais representativos do seu governo: o fechamento do templo de Jano (25 d.C.), que simbolizava o fim da guerra, e a construção do Ara Pacis (11 d.C.), emblema político-religioso da Pax Romana, sinais que colaboraram para a consolidação do Imperium Romanum como entidade política unificada 
no imperador. A Paz, até então desconhecida, passou a ser vista como a maior realização da época de Augusto (GALINSKY, 1996, p. 6-10; ACOSTA BONILLA, 2007, p. 29-33).

As realizações de Augusto muito impressionaram o povo e provocaram a sua exaltação mítica como príncipe e criador de um reino de paz. No ano 27 a.C., o senado romano o declarou theos sebastos. No ano 17 a.C., jogos foram celebrados em honra ao nascimento de uma nova era, que seria governada pelos valores antigos como fides, pax, honor, pudor e virtus. A tendência romana de divinizar conceitos abstratos favoreceu a veneração de virtudes, como a concórdia, a vitória, a clemência, a justiça e a paz augusta. Essas virtudes eram refletidas e personificadas na imagem do imperador Augusto. As relações de poder sob Augusto expressavam, portanto, uma fusão entre política e religião. Elas se expressavam, entre outras coisas, na construção de imagens, templos e na celebração de festivais imperiais (ZANKER, 1988). Na base da maioria das imagens de Augusto estava a inscrição: "Aqui está Augusto, símbolo do império, o garantidor da paz". Em outros casos a inscrição evocava as ideias de piedade, de Augusto como custódio da fé e tradição. O nome Augusto passou a ser o título imperial por meio do qual os seus sucessores eram reconhecidos. Significava "venerado", "consagrado" ou "adorado", e foi traduzido para o grego como Sebastos.

A Pax Romana, principal dádiva e atributo do imperador Augusto, tornou-se, na ideologia cultural, religiosa e política, legitimadora do império e um dos atributos políticos do culto a Augusto. O culto imperial, então, "tornou-se um laço de unidade do império e símbolo da fidelidade ao imperador e ao Estado e envolvia rituais religiosos, os quais não eram eventos passageiros, mas cultos realizados para o imperador em sua ausência e regulamente institucionalizados" (WENGST, 1991, p. 74-75). A sua forma e escala variava de cidade para cidade, dependendo dos recursos financeiros dos patronos individuais e tamanho e status da comunidade. As elites das cidades conquistadas adotavam as práticas romanas como tentativa de adquirir prestígio a partir da cultura do poder governante, algo crucial para a ascensão dos indivíduos e das comunidades.

O culto imperial difundiu-se como um fenômeno complexo e diversificado, de acordo com o tempo e as áreas geográficas: o imperador representava o império de tal modo que o bem comum repousava na sua integridade (WENGST, 1991, p. 75). A “paisagem cultural da Ásia romana tornou-se permeada por templos, festivais e rituais que envolviam 
os imperadores e a família imperial, os Sebastoi". O reconhecimento e a participação no culto imperial envolviam toda a vida cívica. Não era apenas uma prática superficial ligada à vida pública das elites, mas vinha de baixo para cima, como forma de honrar os governantes (PRICE, 1984, p. 99-101). Diversas práticas rituais colaboraram para a sua difusão, entre as quais se destacam sacrifícios e orações, cultos de mistérios e associações, templos e sacerdotes, imagens e festivais.

a) Sacrifícios e orações - $\mathrm{Na}$ teologia imperial romana o imperador tornou-se mediador e, mais tarde, destinatário direto e exclusivo de sacrifícios que, a princípio, eram vistos como a mediação entre deus e o ser humano e oferecidos para o bem-estar comum. Ele adquiriu, ainda em vida, uma posição entre a humanidade e a divindade. Os sacrifícios eram vistos como uma resposta a um favor recebido. Em situações de angústia ou de um problema insolúvel, promessas ou juramentos eram feitos à divindade e, uma vez obtido o favor, agradecia-se como sacrifício por meio do imperador. Esse costume favoreceu o desenvolvimento do culto imperial, pois da mesma forma que se pedia um favor aos deuses, a prática de pedi-la ao imperador foi iniciada. Sacrifícios e orações eram feitos na presença do imperador, ou em seu nome junto às famílias aristocráticas imperiais (FISHWICK, 1978, p. 1.201-1.253; KLAUCK, 2011, p. 76-78).

b) Cultos de mistério e associações - A veneração do imperador assumia, algumas vezes, a forma dos cultos de mistério. As estátuas dos deuses, dos imperadores e os objetos sagrados do culto de mistério tinham um papel ritual e político, constituindo uma superposição de piedade e império. As associações, de natureza e origem variada, envolviam aspectos da família e da polis (BERNABE UBIETA, 2006, p. 99-125). Algumas delas surgiram em torno da pessoa do imperador, suas reuniões eram presididas por uma divindade ou imagem imperial, à qual honravam com cultos e banquetes. O culto das associações legitimava e difundia a autoridade do imperador, exaltava a sua figura divinizada e reproduzia nas cidades o modelo sociopolítico imperial (ACOSTA BONILLA, 2007, p. 51-52; KLAUCK, 2011, p.78-79).

c) Templos e sacerdotes - Os templos romanos tinham diversas funções, todas marcadas político-religiosamente: eram locais das principais reuniões das cidades, bancos, centros de cultura, de encontro e de propaganda política. A referência principal de uma cidade era o seu templo, que era conhecida pela honra a ele atribuída. Um templo podia ser dedicado a uma 
divindade, mas nele a imagem do imperador era colocada no lugar mais estratégico, onde tivesse mais visibilidade. A família do imperador ocupava também um lugar importante, pois os templos eram dedicados a ele e a sua família como expressão de lealdade e filiação da aristocracia, que construía e dava nome ao templo, mas tais construções eram subvencionadas pelos impostos que as classes baixas pagavam. Os sacerdotes que exerciam o ofício nos templos imperiais supervisionavam a correta observação e celebração dos ritos ao imperador. Os ofícios sacerdotais eram especialmente concedidos à aristocracia como prêmio por uma vitória militar e, por meio deles, o culto imperial desempenhava uma função social, oferecendo às famílias aristocráticas uma maneira de adquirir prestígio e honra pública na cidade, ligação com a casa e ideologia imperiais e uma forma de expressar lealdade ao imperador (ZANKER, 1988, p. 316-333; KLAUCK, 2011, p. 81-82, 84-86).

d) Imagens - A imagem do imperador, colocada no centro da cidade ou no seu templo como símbolo de unidade e de pertença era uma forma pública de culto imperial. Isso significava que a cidade estava sob a proteção do imperador e sua imagem um ponto de referência para a homogeneidade do culto imperial. Sacrifícios, festivais ou banquetes eram celebrados diante de suas imagens, que eram coroadas e carregadas em procissões festivas. A imagem do imperador, que inicialmente representava a sua pessoa, aos poucos converteu-se numa expressão da onipresença divina, símbolo da unidade visível do Estado composto por muitos povos e efígie vinculante de vários grupos étnicos, comunidades, organizações políticas e sociais. A imagem do imperador cunhada nas moedas era também outra forma privilegiada de culto. A imagem cunhada era símbolo do poder do imperador, de persuasão para aqueles que a usavam, além de compromisso de adoração e de pagamento de imposto. As moedas simbolizavam um meio privilegiado de culto e a posse da moeda significava o reconhecimento dos atributos divinos do imperador (KLAUCK, 2011, p. 79-81).

e) Festivais - Os festivais, celebrados anualmente, eram acompanhados de sacrifícios, procissões, jogos e concursos de música. Eles coincidiam com o aniversário do imperador, o aniversário de sua ascensão ao trono ou do culto imperial na cidade, a celebração do ano novo e das colheitas e assumiam também grandes proporções quando o imperador visitava uma cidade. O encontro do imperador com as autoridades locais era político propagandístico. Por ocasião da sua chegada a uma cidade, havia uma procissão, encabeçada pelas principais pessoas, que iam ao encontro do imperador e do seu cortejo 
político e militar fora dos seus muros. Saudações eram trocadas no lugar de encontro, as quais continuavam dentro da cidade. Havia sacrifícios e jogos pela presença do imperador. A aristocracia local recebia a aprovação do imperador e lhe apresentava o progresso alcançado e as dificuldades no governo da cidade. Havia competição e rivalidade entre as províncias por causa da importância desse encontro, havendo mesmo nos templos imperiais um calendário das principais festas anuais em honra ao imperador (HARMON, 1978, p. 1.440-1.468; KLAUCK, 2011, p. 82-84).

\section{2 - O culto imperial e o Apocalipse de João}

As visões do Apocalipse são profundamente marcadas por seu mundo social. Isso não significa que João reproduza os elementos procedentes de sua sociedade. Como profundo articulador cultural e religioso, o visionário interage com sua realidade dando-lhe novas perspectivas, invertendo-as, inclusive. Isso não é diferente no que se refere ao culto imperial. O profeta João refuta com violência o culto ao governante por meio de críticas, de associações imagéticas negativas etc., e, ao mesmo tempo adapta elementos do culto ao governante oriental para representar a corte celeste, a veneração de Deus e do Cordeiro. Deus é visto como um basileus venerado por anjos e seres divinos da mais alta patente. A crítica mordaz encontramos de forma mais enfática no capítulo 13, no qual o Imperador e o sacerdócio do seu culto são descritos como monstros violentos e assustadores. A adaptação de motivos do culto imperial ao culto celestial encontramos nos capítulos 4 e 5 , nos quais Deus e o Cordeiro recebem aclamações, doxologias, hinos, genuflexão e demais honrarias e devoções. Essas adaptações são profundamente contraculturais, ousando dirigir ações de culto tradicionalmente voltadas para reis orientais para a divindade judaica e seu messias crucificado. Vamos agora listar algumas dessas adaptações de imagens do culto imperial com funções de crítica ao mesmo.

\subsection{Adaptações e inversões de imagens dos mistérios imperiais}

a) Anjos e taças - A aparição do sumo sacerdote no início de uma nova série de jogos, ou quando oferecia a libação, era uma cena festiva. João apresenta anjos que derramam as "taças da ira de Deus" sobre os "homens que traziam a marca da marca do monstro e adoravam a sua imagem" (16,2). Os sete anjos, com suas taças, iniciam um jogo na narrativa apocalíptica, mas 
o que ocorre é a batalha final entre a Babilônia e os seguidores do Cordeiro, sendo essa também a arena em que acontece o Armagedon e os "ais" da tribulação apocalíptica (16,3-21). O incenso, o sacrifício de um touro e o simbolismo do imperador, como sacerdote com o traje para o sacrifício, e a oferenda de libação era prática comum do culto imperial. A visão dos anjos e de suas taças pode ter sido extraída dessas imagens ou até mesmo das imagens das sacerdotisas de Pompeia com suas estolas e taças. O imperador trazia bênção e salvação por meio da libação. Para João, os anjos, ao contrário, trazem ira e julgamento sobre os que adoram a imagem do monstro (BRENT, 1999, p. 193).

b) Os anciãos ao redor do trono - Nos capítulos 4 e 5 João apresenta 24 anciãos, provavelmente anjos ministros, em torno do trono divino e diante da entronização do Cordeiro. O tema da corte oriental que oferece honrarias, deferências e culto ao governante divino é invertido na corte celeste. Os anciãos se prostraram diante de Deus e entoavam hinos em seu louvor. Essa cena e suas imagens constitutivas não dependem do culto imperial para serem visualizadas pelos ouvintes e leitores do Apocalipse. Elas provêm do culto a Deus no Templo de Jerusalém e não se distanciam muito de outros cultos a divindades orientais. No entanto, não passaria despercebido a um ouvinte e leitor da Ásia Menor a homologia e inversão de temas em relação ao culto imperial. A cena de Apocalipse 4 e 5, apesar de oferecer imagens conhecidas e convencionais, é uma provocação muito planejada ao culto do governante, percebido como ilegítimo. O capítulo 5 acirra ainda mais essa provocação ao entronizar o "Cordeiro que parecia ferido de morte", ou seja, um crucificado pelos romanos. Outros aspectos também adaptam e invertem elementos do culto imperial, como a descrição da adoração do Cordeiro, que é feita a partir da linguagem enigmática dos mistérios (BRENT, 1999, p. 193-196).

c) $\mathrm{O}$ incenso e as almas dos mortos debaixo do altar - No Apocalipse, o incenso está associado com o altar celestial e as almas debaixo do altar (6,911). O incenso é também mencionado após a abertura dos sete selos (8,3-4), onde um anjo, em pé junto ao altar, oferece incenso não como propiciação pelas almas divinizadas dos que já haviam morrido, mas como as orações do povo de Deus. Os mártires cristãos são descritos como "as almas dos que tinham sido imolados por causa da palavra de Deus e do testemunho que tinham" (6,9), tema que está presente na literatura da sabedoria (Sab 3,1-9), mas a associação entre o seu culto e o altar ainda não havia acontecido. $\mathrm{O}$ termo descanso, que descreve os membros do coro imperial já mortos é 
o mesmo utilizado na apresentação dos mártires cristãos, mas a descrição das almas dos que receberam uma ordem para descansar indica que a contraimagem do culto imperial é responsável pela descrição dessa cena celestial (BRENT, 1999, p. 197-198).

d) Orações e cânticos - As cenas localizadas diante do altar celestial, como as orações dos anciãos, anjos e grande multidão, o hino dos 144 mil mártires, refletem a fala dos anciãos ou os cânticos das celebrações imperiais. O hino cantado pelos 144 mil mártires, paralelo ao culto imperial, alude aos ritos de mistério num contexto musical: "E ouvi uma voz que vinha do céu, como a voz dos oceanos, como o ribombar de forte trovão: e a voz que ouvi era como o canto de harpistas tocando as suas harpas. Cantavam um cântico novo diante do trono, diante dos quatro animais e dos anciãos. E ninguém podia aprender esse cântico, a não ser os cento e quarenta e quatro mil, os redimidos da terra" (14,2-3). Antes do hino, as orações dos 24 anciãos $(4,10)$, da grande multidão $(7,9)$ e dos anjos em volta do trono $(7,11)$ não aludem diretamente aos mistérios imperiais, mas pertencem ao contexto do hino dos 144 mil mártires (BRENT, 1999, p. 199-201).

O pano de fundo cênico dos cânticos dos anciãos, anjos ou dos 144 mil mártires deriva, sem dúvida, do culto. O trono diante do qual os anciãos se prostram e adoram é o trono do Cordeiro. O altar de ouro está diante do trono $(8,3)$. O Cordeiro está no trono e, embora tenha sido morto, vive e compartilha do trono de Deus $(5,6)$. A grande multidão usa "vestes brancas e tem palmas brancas nas mãos" $(7,9)$. O sacrifício no altar celestial é do Cordeiro, em cujo sangue a grande multidão lavou e alvejou as suas vestes $(7,14)$. O hino de salvação de Apocalipse 7,10 declara: "a salvação é do nosso Deus, que está sentado no trono, e do Cordeiro". O primeiro cântico foi entoado pelos 24 anciãos com coroas de ouro nas cabeças e vestes brancas $(4,4.11)$. Os oficiais chamados anciãos, o uso de coroas e assentos de honra caracterizavam o culto imperial em muitas cidades da Ásia Menor (BRENT, 1999, p. 201-202).

e) Os anciãos, assentos de honra e coroas de ouro - A apresentação dos anciãos tem a sua contraparte no culto imperial. Eles são judeus ou cristãos que participam da liturgia da sinagoga ou da igreja, mas esses conceitos são exibidos como imaginação contracultural. No culto imperial, havia oficiais que ocupavam assentos de honra no culto. É significativo que os anciãos também usem coroas de ouro, pois alguns cidadãos usavam coroas comuns em suas reuniões. O lançamento das coroas pelos anciãos 
diante do trono $(4,10)$ é paralelo ao culto imperial, pois era prática comum apresentar o governante divino com uma coroa de ouro e adorá-lo diante de sua cadeira vazia. As orações dos anciãos são quase idênticas às orações da grande multidão e dos anjos, e cada um dos seus cânticos lembra o cântico dos senadores no Capitólio durante o reinado de Gaio. Esses cânticos repetem conceitos comuns como glória, ação de graças, honra, poder, riqueza, sabedoria e salvação $(5,13 ; 7,10-12)$, uma linguagem que se aproxima dos modelos de cânticos do culto imperial (BRENT, 1999, p. 202-208).

f) $\mathrm{O}$ trono de Satanás - Na carta à comunidade de Pérgamo, o Cristo ordena a João que transmita essa mensagem: "Conheço o lugar em que vives, que é onde está o trono de Satanás, e que guardas meu nome e não negaste minha fé nos dias de Antipas, minha testemunha fiel, que morreu entre vós, onde Satanás habita" $(2,13)$. Não podemos tomar essas cartas ditadas pelo próprio Filho do Homem a João, para que ele as transmitisse aos anjos das respectivas igrejas, como um relato preciso da situação concreta das igrejas cristãs da Ásia Menor. Há projeções de tensões, medos e angústias que não nos permitem reconstruir a vida dessas comunidades às quais o Apocalipse foi endereçado. No entanto, as informações citadas são muito marcantes: João fala de um lugar em Pérgamo que é um "trono de Satanás" e que em relação a ele um membro da comunidade, de nome Antipas, morreu. Esse versículo gerou várias hipóteses na pesquisa.

No texto parece clara a relação entre o "trono de Satanás" e a morte de Antipas. Ele deve ter sido vítima de morte violenta, por execução, seja oficial, seja por ação espontânea do populacho, em um lugar específico de Pérgamo. A pesquisa tem basicamente quatro hipóteses para a localização do "trono de Satanás", segundo levantamento feito por Steven Friesen (2005). Esse local seria: (1) O Altar de Zeus e de Atenas na acrópole de Pérgamo, (2) O Asklepeion, um conjunto de edifícios e instalações dedicadas ao culto de Asclépio, na periferia da cidade, (3) uma referência à cidade de Pérgamo como um todo, como suposto centro do culto imperial na província romana da Ásia, e (4) o templo de localização desconhecida dedicado a Roma e Augusto. Se ainda considerarmos que o Apocalipse, ou parte de sua redação, pode ser datado do começo do século II, valeria listar o Trajaneum, um magnífico templo dedicado ao culto do Imperador Trajano, construído na acrópole.

2 Apesar de Friesen (2005) constatar que os intérpretes do século XX terem abandonado a relação com o Altar de Zeus e de Atenam, Adela Yarbro Collins, em um artigo de 2005, defende essa hipótese com vigor. 
Não temos espaço suficiente para debater todas essas hipóteses. No entanto, no espírito da interpretação que damos aqui à forma como o visionário João se relaciona com o culto imperial, seja no sentido de emular e adaptar suas formas, seja no de debochar dele, por meio de sátiras e de imagens grotescas, queremos adicionar uma hipótese para interpretar o "trono de Satanás". A exegese histórico-crítica tem certa obsessão em identificar dados históricos e instituições com precisão, como se João quisesse dizer com "trono de Satanás" única e exclusivamente um lugar. De fato, ele poderia tê-lo feito. No entanto, nós não dispomos dos instrumentos e recursos necessários para reconstruir essas identificações. É mais provável que ele tenha feito referências mais gerais, que favorecem a ambiguidade das associações jocosas. Quando os brasileiros se queixam de "Brasília", o fazem sem muita especificidade. Nesse conceito cabem muitas instituições da capital, que são relacionadas à má fama do poder. Por isso, é melhor falar da "capital" ou apenas "o Planalto" ou "Brasília" genericamente. Se o leitor buscar na internet uma imagem da acrópole de Pérgamo, verá que na sua encosta sul, na sua fachada principal, está encravado o teatro da cidade. Visto com um pouco de imaginação esse teatro pode ser considerado um grande assento sobre o qual Satanás coloca suas gigantescas nádegas. Nesse sentido, toda a acrópole, o centro administrativo da Pérgamo imperial e, por consequência, todos os espaços públicos e templos daquela parte da cidade eram extensão do "trono de Satanás". Imagino os primeiros cristãos olhando para a acrópole, para o teatro, em especial, e zombando: ali Satanás se assenta.

\subsection{Os monstros do mar e da terra (Ap 13.1-8.11-17)}

Apocalipse 13 apresenta dois monstros: o primeiro, do mar $(13,1-8)$, o segundo, da terra (13,11-17). As imagens utilizadas na descrição do monstro do mar indicam a sua natureza, a qual, como o dragão, isto é, o "Diabo, e Satanás” (Ap 12,9), está associada ao caos que ameaça a criação e o povo de Deus (PEERBOLTE, 1996, p. 142): "Vi, então, um monstro subir do mar, tendo dez chifres e sete cabeças. Sobre seus chifres, dez diademas, e sobre suas cabeças, nomes de blasfêmia. O monstro que vi era semelhante a um leopardo; seus pés, como de um urso; sua boca, como boca de leão. O dragão lhe deu seu poder, seu trono e grande autoridade" (13,1-2). Ele provoca espanto em toda a terra, pois a ferida mortal que recebeu em uma de suas cabeças foi curada: "Uma de suas cabeças estava como que imolada de morte, mas esta ferida de morte foi curada. Toda a terra ficou maravilhada, 
seguindo atrás do monstro. E adoraram o dragão, porque deu autoridade ao monstro. Adoraram o monstro, dizendo: 'Quem é igual ao monstro e quem tem poder para lutar contra ele"' (13,3-4). Ele recebeu também "uma boca que falava blasfêmias" (13,5-6). O mundo adora o Dragão e o monstro e reconhece sua grande capacidade militar: "E foi-lhe dado fazer guerra contra os santos e vencê-los. Foi-lhe dada autoridade sobre toda tribo, povo, língua e nação. Então o adoraram todos os habitantes da terra, os que não têm seus nomes escritos no Livro da Vida do Cordeiro, que foi imolado desde a fundação do mundo" (13,7-8).

O monstro está ligado ao dragão, o poder que se opõe a Deus, que "lhe deu seu poder, seu trono e grande autoridade" $(13,2)$. O dragão representa uma ameaça cósmica, mas o monstro representa uma ameaça terrestre (HIEKE, 2012, p. 53-55; AUNE, 1997, p. 728). Além disso, após a menção de que "uma de suas cabeças estava como que imolada de morte, mas esta ferida de morte foi curada", que se refere à lenda do Nero redivivus (ROLOFF, 1993, p. 155; AUNE, 1997, p. 737-740; BEALE, 1999, p. 687693), o texto apresenta a reação dos habitantes da terra diante do dragão e do monstro (13,3-4). Os habitantes da terra se maravilharam diante dele porque sua cabeça foi curada, e adoraram o Dragão que lhe deu autoridade. $\mathrm{Na}$ tradição judaica, somente Deus é digno de adoração e uma característica importante do adversário escatológico encontrada nos escritos judaicos é que ele nunca exige ser adorado como Deus, nem afirma que é Deus. O Apocalipse, contudo, utiliza o verbo "adorar" em relação ao monstro como expressão do protocolo do culto imperial (AUNE, 1997, p. 740-741).

Esse monstro recebeu também uma boca que proferia palavras arrogantes e de blasfêmia contra Deus, o seu nome e o templo. Blasfemar contra Deus é uma característica do adversário escatológico encontrada em muitas passagens da tradição bíblica (Dn 7,24-27). Há também blasfêmias proferidas contra o templo e os santos que nele habitam. O monstro recebe também permissão para guerrear contra os santos e vencê-los, sendo-lhe dada "autoridade sobre toda tribo, povo, língua e nação". Por conseguinte, os habitantes da terra que não estão inscritos no livro da vida do Cordeiro adoram o monstro. As consequências provocadas por sua atividade envolvem todo o mundo, confirmando sua natureza demoníaca. Suas sete cabeças e dez chifres conferem proporções cósmicas à imagem do poder vigente, além de indicar uma semelhança física com o grande dragão, a antiga serpente, diabo, Satanás. A imagem do monstro do mar, que recebeu o seu poder, trono e 
grande autoridade do dragão, não de Júpiter ou do Olimpo (FRIESEN, 2001, p. 175-176, 201-202), é moldada por outro monstro, que "subia da terra", que procura levar os habitantes da terra a adorá-lo.

O monstro que "subia da terra", o segundo monstro, é também responsável pela promoção do culto imperial (13,11-17). É uma figura subordinada, mas tem um papel importante no sistema imperial. É subordinado, pois sua autoridade deriva do primeiro monstro e promove o seu culto. É um dragão disfarçado de Cordeiro: tem "dois chifres como cordeiro" e fala "como dragão" $(13,11)$, sendo a sua atividade primária seduzir as pessoas por meio dos sinais que realiza, fazendo que o povo adore o "monstro que sobe do mar" e que impõe sua vontade a todo o mundo $(13,12$ 17). Referido como falso profeta $(16,13 ; 19,20 ; 20,10)$, representa a autoridade do primeiro monstro $(13,12,16-17)$ e é responsável por organizar e reforçar a obediência. Seduz os habitantes da terra e os exorta a adorar o primeiro monstro (13,13-15). Sua capacidade de realização deriva do monstro do mar e, como servo, sua função tem caráter religioso, pois faz que os habitantes da terra a adorem. Ele faz isso com o poder que lhe foi outorgado pelo seu chefe, confirmando sua identificação com o poder político vigente.

Com o poder que lhe é conferido pelo primeiro monstro, o segundo monstro seduz os habitantes da terra, levando-os a adorar o primeiro monstro por meio de sinais e maravilhas. Ele faz descer fogo do céu à terra diante das pessoas $(13,13)$ e procura validar sua autoridade profética a partir da tradição do Antigo Testamento (Êx 4,17,30). O verbo "seduzir", parte do campo semântico do Dragão e dos monstros, detentores do seu poder, significa enganar e está também relacionado ao exercício de poder (FRIEDRICH, 2005, p. 233-262). "Enganar" é uma característica de muitos oponentes escatológicos (1 Enoque 54,5-6; 68,28). O oponente escatológico promove o culto imperial, provavelmente o motivo que leva João a denunciá-lo como falso profeta $(13,14 ; 16,13 ; 19,20 ; 20,10)$. A ordem de fazer uma "imagem do monstro" envolve o argumento com o qual o falso profeta incita à adoração, à cura milagrosa da "cabeça que foi ferida de espada". O monstro da terra também recebe autorização para dar espírito à imagem do monstro, para que ela falasse, e os sinais de fogo que faz cair do céu diante dos homens relembram as demonstrações proféticas de Elias (1 Rs 18,38; 2 Rs 1,10-14). A tradição de grandes sinais realizados no contexto da autoridade profética, de forma negativa, estava bem difundida na tradição cristã (2 Ts 2,9; Mc 13,22; 2 Pe 2,1). 
O monstro da terra apresenta-se como quem anuncia a verdade, que se expressa na identificação com o Cordeiro, mas ele é, de fato, um falso profeta. Com sua representação, João apresenta outro aspecto da sociedade imperial: a autoridade demoníaca das elites locais que colaboravam com Roma. Os oficiais do culto imperial e os candidatos às funções governamentais eram das famílias ricas e proeminentes. O governo e a piedade não estavam separados, nem tampouco os líderes dessas atividades compunham grupos distintos. Essas famílias e a população apoiavam entusiasticamente e ajudavam a expandir o culto imperial. Elas conduziam sacrifícios, festivais, construíam templos, votavam honrarias como parte de seus deveres cívicos e mobilizavam as massas em apoio ao imperador. O poder romano distante governava, enquanto as elites locais colaboravam na pacificação e estabilização de suas regiões (FRIESEN, 2001, p. 202-203). O governo e a piedade não estavam separados, nem tampouco os líderes dessas atividades eram grupos distintos.

Nesse sentido, um aspecto importante da discussão de Apocalipse 13 é a questão da legitimidade. Para João, havia formas demoníacas e divinas no mundo, mas o que estava em jogo era a forma como essas forças se legitimavam. Essas formas eram legitimadas por meio do culto. João, contudo, apresenta o contraste entre elas: a autoridade de Deus e do Cordeiro era própria, estava baseada na natureza de Deus como criador e nas ações de Jesus como redentor. A autoridade do dragão e do monstro do mar ancoravase na força, violência, por um lado, e na sedução e no embuste, por outro lado. Quando o Dragão é identificado com Satanás, é descrito como o "sedutor de toda a terra". A atividade primária do monstro da terra é seduzir, o que é acompanhado pelos grandes sinais que realiza, levando o povo a adorar o monstro do mar, o qual tem uma habilidade guerreira incomparável e impõe sua vontade a todo o mundo. Uma ferida aparentemente fatal em uma de suas cabeças não pode derrotá-lo. Com essas imagens, portanto, João retrata de forma razoavelmente acurada uma das pressuposições básicas do culto imperial: a autoridade romana fundamentava-se na habilidade de subjugar os inimigos e de seduzir os aliados. Não era possível nem se deveria resistir ao poder dos imperadores romanos (FRIESEN, 2001, p. 203-204).

Podemos observar que nessas visões que apresentam o Imperador e o culto imperial como monstros entram em ação dois recursos aparentemente irreconciliáveis, mas que tornam a retórica desse texto muito poderosa e eficiente. O texto joga com elementos do horror, como na descrição das características animais que o transformam em um ser ultraviolento, mas 
também tem elementos jocosos, quando afirma que o segundo monstro realiza milagres e que "lhe foi dado dar sopro de vida à imagem do monstro, para que a imagem do (primeiro) monstro falasse..." $(13,15)$. Aqui ele é descrito como um embusteiro charlatão. Essas características dos monstros nos ajudam a imaginar as reações emocionais e as sensibilidades dos primeiros cristãos diante do culto ao imperador. Deviam se perguntar, desde sua perspectiva como grupo subalterno, como era possível adorar o representante de um poder tão violento, por meio de uma imagem estática e muda.

\subsection{A prostituta e a cidade (Ap 17-18)}

Apocalipse 17-18 descreve a queda da Babilônia e o colapso do mundo associado a ela. Nesses capítulos, a simbolização do centro imperial muda de um "monstro com sete cabeças e dez chifres" para uma caricatura grotesca de uma "prostituta", visitada pelos reis da terra (Ap 17): uma mulher vestida com os acessórios de luxúria e corrupção, "uma meretriz assentada sobre muitas águas" (17,1.15), "montada num monstro escarlate, cheio de nomes de blasfêmia, com sete cabeças e dez chifres" $(17,3)$, "embriagado com o sangue dos santos e das testemunhas de Jesus" (17,6; 18,6.20.24; 19,2). A prostituta é também uma cidade, Babilônia (18,2.4.10.16.18-19.21), também chamada de mulher (18,3.7-16). Descrita como "Babilônia, a grande (18,2), "a grande cidade" (18,10.16.18), "grande e poderosa cidade" $(18,10)$, a sua destruição será repentina: “em um só dia virão as suas pragas $(18,2.8)$; será queimada (18,8); foi julgada (18,10.20); sua riqueza devastada (18,17.19). Com a sua destruição $(18,14.21 .22 .23 \mathrm{ab})$, a cidade ficou privada de todas as suas riquezas $(18,12-13.16)$.

João destaca os crimes pelos quais a prostituta é julgada ao utilizar a imagem da má conduta sexual e intoxicação. Os reis da terra se prostituíram com ela "e os moradores da terra se embriagaram com o vinho fúria da sua prostituição” (17,2.4.9.12.14.18; 18,3.9). Há também uma imagem da relação da prostituta com o monstro antes mencionado na declaração de que ele é "escarlate, cheio de nomes de blasfêmia, com sete cabeças e dez chifres" $(17,3)$, características atribuídas ao dragão e ao primeiro monstro (12,3; 13,1). Ele está repleto de nomes de blasfêmia $(17,3 ; 12,3 ; 13,1)$, também uma característica do primeiro monstro $(13,1.5-6)$, está vestido de púrpura e escarlate $(17,4 ; 18,12.16)$, adornado de ouro, pedras preciosas e pérolas $(17,4$; 18,12.6) e tem nas mãos "um cálice de ouro cheio das abominações e das impurezas da sua prostituição" (17,2.4.5; 18,3). A imagem da "prostituta”, 
cujas raízes podem ser encontradas na literatura profética judaica, foi aplicada pelos profetas de Israel a Tiro e Nínive (Is 23; Na 3,4). O profeta Ezequiel repreende a Samaria e a Jerusalém por suas alianças com potências estrangeiras, qualificando-as de prostituição (Ez 16).

A imagem utilizada para descrever essa entidade corporativa tem grande potencial como retórica contra a autoridade romana. Parte disso se deve ao seu potencial para a polêmica contra o politeísmo, mas o objetivo do Apocalipse não é simplesmente classificar Roma como politeísta. O politeísmo não era apenas parte da sociedade greco-romana, mas a sua base. Do ponto de vista de João, o império romano tornara o erro e arrogância do politeísmo uma grande blasfêmia ao lhe acrescentar a exaltação dos imperadores. A imagem da "prostituta" faz que a objeção de João ao imperialismo romano ultrapasse o contexto do culto, pois a metáfora possibilita fazer as conexões necessárias entre culto, comércio, política e o império em sua crítica. A "reserva de significado" da imagem do "monstro de sete cabeças e dez chifres" tinha mais o sentido de força e violência, mas a imagem da prostituta oferece recursos simbólicos para denunciar a idolatria, a dominação política e a exploração econômica. Nesse sentido, Apocalipse 17 estabelece uma transição entre esses símbolos ao mencionar ao mesmo tempo a besta e a prostituta. $\mathrm{Na}$ medida em que o texto começa a detalhar a blasfêmia do império romano em Apocalipse 18, a prostituta torna-se o ponto central (FRIESEN, 2001, p. 205).

A prostituta é uma cidade e a cidade tem um nome: Babilônia (17,5.18), o qual tem muitas associações na história bíblica. Da mesma forma que as imagens de prostituta derivam da literatura profética, João fundamenta sua crítica nos textos proféticos, especialmente os cânticos de lamento fúnebre sobre Tiro (Ez 26,15-18 e 27,1-8.26-36) e os oráculos contra a Babilônia (Jr 50-51; Is 13-14; 23; 47). Os oráculos de Ezequiel contra Tiro e seu rei demonstram como João apresenta a queda da cidade, cujo nome deriva das associações tradicionais ao significado da Babilônia na tradição profética. Os oráculos de Ezequiel 26-27 denunciam a cidade de Tiro porque ela se alegrou quando os babilônios destruíram Jerusalém, sendo aquela tragédia considerada como uma oportunidade para aumentar a participação no comércio regional. Ezequiel 26,2-13 descreve a reação de outros governantes sobre a súbita destruição de Tiro (Ez 26,15-18). O oráculo finaliza com a declaração de que Javé provocará a queda da cidade imperial (Ez 26,19-21). Ezequiel 27 contém um lamento no qual a cidade de Tiro é descrita como um navio mercante. 
As mercadorias e os parceiros comerciais são apresentados (27,3-11.25-27) e os pilotos e marinheiros, em pé na areia da praia, lamentam a queda da cidade (27,32a-33) (FRIESEN, 2001, p. 205).

A presença em Apocalipse 18 dos temas como mar e comércio marítimo, dos "reis", "mercadores" e "marinheiros", de riquezas, da lista de mercadorias (18,12-13), do orgulho e palavras arrogantes $(18,7)$ indica uma releitura de Ezequiel 26-27 e a crítica econômica como um dos componentes inovadores do Apocalipse. João descreve a luxúria e orgulho da Babilônia $(18,3)$, mas quando a cidade cai, com ela se rompe toda uma rede de relações. Os grupos a ela associados: os "reis", que com ela "adulteraram e viveram em luxúria (18,9-11), os "mercadores", que se enriqueceram a partir do domínio do comércio marítimo, lamentam a destruição das riquezas da capital (18,1117a), os marinheiros, que lamentam as oportunidades perdidas de ganhar mais dinheiro (18,17b-19), compartilham do seu destino. Eles "choram e lamentam", de longe vem a sua destruição, dizendo: "ai, ai, da grande cidade" $(18,10.16 .19)$.

Ezequiel 26-27 fornece as imagens para a crítica dos aspectos econômicos, mas os oráculos contra a Babilônia de Jeremias 50-51 oferecem outras imagens de Apocalipse 18 (FRIESEN, 2001, p. 206). Primeiro, Babilônia é descrita como "uma taça de ouro sustentada pela mão de Javé como seu instrumento de vingança contra as nações" (Jr 51,7). Na visão de João, a responsabilidade pela loucura das nações muda, pois agora a Babilônia torna-se uma prostituta que oferece uma taça de vinho aos habitantes da terra: "as nações da terra se embriagaram com o vinho do furor da sua prostituição" $(18,3)$. A prostituta sustenta a taça, da qual outros bebem $(14,8 ; 17,2.4)(14,10)$. João destaca essas dimensões e assinala que a Babilônia beberá da sua própria taça $(14,10)$ : "Dai-lhe como também ela deu, dai-lhe em dobro segundo as suas obras. No cálice em que ela misturou, misturai em dobro para ela" (18,6; cf. 14,10); "dai-lhe em dobro segundo as suas obras" e "preparar a taça" são expressões da lex talionis ( $\hat{E x} 22,4.7$; Jr 16,16-18; 50,29; 51,34-40). João combina a noção da dupla retribuição com a imagem da taça, a metáfora da intoxicação: Babilônia beberá uma dupla porção de sua própria taça, de acordo com as suas obras. Nessa irônica inversão, a imagem aplicada à influência intoxicante da Babilônia sobre as nações é também a imagem que descreve a sua sentença $(16,19 ; 17,2.4 ; 18,6)$. Suas abominações envolvem transgressões na esfera do culto, mas essa realidade tem raízes na realidade política e econômica. Segundo, a ordem para deixar 
a cidade e se alegrar com a sua queda $(18,4-5.20)$ tem como base Jeremias 50,$8 ; 51,6.9 .45$, embora haja também ressonância de outros textos proféticos (Is 48,20; 52,11) (FRIESEN, 2001, p. 206). O povo de Deus é exortado a romper a sua relação com a Babilônia para não compartilharem do seu pecado e, desse modo, não serem condenados. "Os pecados da cidade chegaram até o céu e Deus lembrou-se das suas iniquidades" (18,4-5). Deus relembra de suas "iniquidades" e o beber da taça da cólera de Deus é especificado como uma retribuição apropriada a suas más ações. Terceiro, a ação simbólica do "anjo forte" (18,21-24), o último e mais dramático lamento da queda da Babilônia (Jr 25,10; 51, 63-64), que depois de escrever os oráculos contra a Babilônia instrui o oficial real a atirar o rolo no Eufrates. No relato de João, a imagem é ampliada, pois após atirar uma grande pedra ao mar, o anjo declara: "Com esta violência, Babilônia, a grande cidade, será lançada e não será mais encontrada" $(18,21)$. A condenação da Babilônia, anunciada por meio da narrativa da ação simbólica do anjo, é inspirada em Jeremias num contexto em que a influência predominante provém dos oráculos contra o rei de Tiro (Ez 26,1-28,19). Os mercadores, apresentados como aqueles que se beneficiavam com a luxúria da Babilônia, desaparecem definitivamente $(18,24)$. O retrato da desolação total da cidade se completa com a extinção das atividades que compõem sua vida social (18,22-23).

A denúncia que se expressa no lamento dos reis, mercadores e marinheiros assinala a destruição do poder imperial e de todas as pessoas que dele se beneficiavam. Trata-se da destruição da Babilônia, a cidade para onde confluíam as riquezas do mundo e onde a idolatria do mundo inteiro, dos pequenos e dos grandes, dos trabalhadores e dos chefes, se manifesta com a mais insuportável luxúria. A descrição da cidade como uma prostituta visitada pelos reis da terra indica tanto a idolatria e envolvimento com o seu comércio quanto o destaque dado à sua autoglorificação e arrogância. O nome Babilônia, dado à grande cidade, e a figura da "grande meretriz" são imagens que estigmatizam a idolatria do culto, bem como o luxo do império. Nesse sistema político que abrange tudo, há aliados que se beneficiam da sua política e estão totalmente associados ao seu projeto: riqueza, orgulho, blasfêmia, atitudes arrogantes e obras injustas estão unidas num mesmo comportamento em passagens que expressam principalmente a certeza de que Deus derruba os soberbos e os injustos. 


\section{Considerações finais}

Há várias imagens do Apocalipse de João extraídas do âmbito do culto imperial, mas elas devem ser entendidas como uma reconstrução judaica e cristã de valores da cultura pagã, na qual a marca daquela cultura se expressa de forma invertida. A descrição das realidades celestiais e mobilização da igreja na terra que o livro apresenta são transformadas por meio da construção de uma realidade contracultural. João assume os valores da cultura greco-romana, mas os inverte. Ele cria sua própria estrutura de referência, um tipo de imagem que espelha a cultura original, a partir da qual aquele que habita essa reconstrução da realidade social encontra o status de autoestima que a cultura de origem lhes nega. O Apocalipse de João exibe também o culto com a descrição das "coisas que ainda devem acontecer". Por essa razão, os cânticos que apresenta expressam a convicção dinâmica e vital de comunidades que afirmavam que viviam no nascimento de uma nova era, sendo também o culto o lugar da atividade hermenêutica de ouvir, compreender e aplicar as palavras proféticas do livro: "A comunidade cristã fiel canta o poder de Deus e a soberania de Cristo. Ao recordar, continuamente, o culto, ao inserir o poder de Deus e de Cristo, cantado no culto em hinos, em contradição direta com o poder vigente, João indica o culto como um lugar de aprendizagem: a confissão de fé na soberania de Deus e de Cristo deve ser entendida como testemunho para o mundo, mas, ao mesmo tempo, como protesto contra toda a soberania que se lhe opõe" (WENGST, 1991, p. 197-198).

\section{Referências}

ACOSTA BONILLA, Manuel de Jesús. El Evangelio de Lucas. Culto al Emperador y Pax Romana. Tese de doutorado. Universidade de Deusto - Espanha, 2007.

ADRIANO FILHO, José. Oráculos Sibilinos III-V: Judeus no Egito helenístico e romano. Identidades fluídas no Judaísmo Antigo e no Cristianismo Primitivo. NOGUEIRA, Paulo (Org.). São Paulo: ANABLUME/FAPESP, 2010, p. 137-162.

AUNE, David E. Revelation 6-16. Word Biblical Commentary. Dallas, Texas: Word Books, 1997.

BEALE, G. K. The Book of Revelation. The New International Greek Commentary. Grand Rapids: Eerdmans, 1999.

BERNABE UBIETA, C. "Asociaciones y Familias en el Mundo del Cristianismo Primitivo." Estudios Bíblicos 64, 2006, p. 99-125.

BRENT, Allen. Imperial Cult and the Development of Church Order. Concepts and Images of Authority in Paganism and Early Christianity before the Age of Cyprian. Leiden: E. J. Brill, 1999. 
COLLINS, Adela Y. Satan's Throne. In: Biblical Archaeology Review May/June 2006, 28-39. FISHWICK, Duncan. "The Development of Provincial Ruler Worship in the Western Empire." Aufstieg und Niedergang der Römischen Welt II, 16.2, 1978, p. 1.201-1.253.

FRIEDRICH, Nestor Paulo. "Manter a identidade e a esperança em meio a um mundo hostil. Desafio da igreja em Tiátira." Religião de Visionários: Apocalíptica e misticismo no Cristianismo primitivo. Paulo A. S. Nogueira (Org.). São Paulo: Loyola, 2005, p. 233-262. FRIESEN, Steven J. Imperial Cults and the Apocalypse of John: Reading Revelation in the Ruins. Oxford: Oxford University Press, 2001.

FRIESEN, Steven J. Satan's Throne, Imperial Cults and the Social Settings of Revelation. In: Journal of the Study of the New Testament, 2005, 27, 351-373.

GALINSKY, K. Augustan Culture: An Interpretative Introduction. Princeton: Princeton University Press, 1996.

GRADEL, Ittai. Emperor Worship and Roman Religion. Oxford: Clarendon Press, 2002.

HARMON, Daniel P. “The Public Festivals of Rome." Aufstieg und Niedergang der Römischen Welt II, 16.2, 1978, p. 1.440-1.468.

HIEKE, Thomas. The Reception of Daniel 7 in the Revelation of John. HAYS, R. \& ALKIER, Stefan (Orgs.). Revelation and the Politics of Apocalyptic Interpretation. Waco, Texas: Baylor University Press, 2012, p. 47-67.

KLAUCK, Hans-Joseph. O entorno religioso do cristianismo primitivo. Culto aos governantes e imperadores, filosofia e gnose. São Paulo: Edições Loyola, 2011.

KÖSTER, H. Introdução ao Novo Testamento. São Paulo: Paulus, 2005.

PEERbolte, L. J. L. The Antecedents of Antichrist. A Traditio-Historical Study of Earliest Christian Views on Eschatological Opponents. Leiden: E. J. Brill, 1996.

PRICE, S. R. F. "Rituais de Poder.” In: Paulo e o império: Religião e poder na sociedade imperial romana. HORSLEY, R. (Org.). São Paulo: Paulus, 2004, p. 53-76.

PRICE, S. R. F. Rituals of Power. The Roman imperial cult in Asia Minor. Cambridge: Cambridge University Press, 1984.

ROLOFF, Jürgen. Revelation. Continental Commentary. Trans. John E. Alsup. Minneapolis: Fortress Press, 1993.

WENGST, Klaus. Pax Romana. Pretensão e Realidade. Experiências e percepções da paz em Jesus e no cristianismo primitivo. São Paulo: Edições Paulinas, 1991.

WOOLF, Greg. "Divinity and Power in Ancient Rome." In: Religion and Power. Divine Kingship in the Ancient World and Beyond. Nicole Brisch (Org.). Chicago, Illinois: The Oriental Institute of the University of Chicago, 2008, p. 243-259.

ZANKER, Paul. The Power of Images in the Age of Augustus. Michigan: The University of Michigan Press, 1988.

Submetido em: 11-2-2019

Aceito em: 11-4-2019 